\title{
Finger ridge patterns and tactile sensitivity
}

\author{
D. Z. LOESCH and N. G. MARTIN \\ Department of Population Biology, Research School of Biological Sciences, Australian National \\ University, Canberra \\ Received 15 November 1982; revised 3 March 1983
}

\begin{abstract}
Summary. Tactile sensitivity has been measured in 101 normal individuals ( 38 females and 63 males) of European origin, and compared with ridge pattern characteristics of the fourth fingertip of the right hand. There is a relationship of tactile sensitivity performance with the type of pattern, particularly in females, and also with the number of junctions within the pattern, particularly in males. The possible origin of sex differences in tactile sensitivity and in its relationships with dermatoglyphic variables is discussed. In spite of sex differences, optimal tactile sensitivity performance seems to be associated with medium-sized loop patterns which have a greater number of junctions than ends and also have grooves wider than ridges. The possible evolutionary significance of these associations is discussed in relation to evidence for epistatic genetic variation for pattern intensity.
\end{abstract}

\section{Introduction}

It is commonly believed that ridge patterns in humans, which occur on the dermal surface of fingertips, palms and soles, are selectively neutral and that their function is limited to moistening the skin. However, in previous studies we obtained evidence for non-additive genetic variation in finger ridge counts (Martin, Loesch and Jardine 1982) and finger pattern intensity (Loesch and Martin 1984), which might suggest a history of natural selection in these traits (Mather 1973).

There has been no serious attempt to obtain direct evidence for the action of selection on ridge patterns except for Babler's (1978) study in which he showed that there is a greater risk of spontaneous abortion of fetuses with low values of finger pattern intensity.

Demonstration of functional correlates of variation in dermatoglyphic patterns may also be taken as indirect evidence against the postulate of neutrality. Several earlier authors speculated in this direction (Schlaginhaufen 1905, Cummins and Midlo 1943, Quilliam 1978), but no specific hypotheses have been tested to our knowledge. One remarkable exception is the early work by Fére $(1895,1896)$ who observed that there was greater dermatoglyphic variation on fingers more involved in motor functions. $\mathrm{He}$ speculated that this variation might be related to perceptive functions necessary for fine motor movement and found relationships between two-point discrimination on the fingertips and certain dermatoglyphic variables. We shall refer to this neglected work more extensively in the discussion.

Some other functions which may be correlated with variation in finger ridges are tactile or heat sensitivity and gripping ability. On a priori grounds, tactile sensitivity seems the most likely candidate, because the ridged surface of the skin with sweat glands situated along ridge lines facilitates the contact of the hand with an object by creating greater resistance and hence greater stimulation of nerve endings. Moreover, dermal papillae of the fingertip ridges contain Meissner's corpuscles which respond to mechanical stimulation of the skin (Ronge 1943, Cauna and Ross 1960, Okajima 1975, Quilliam 1978).

To test the hypothesis that there is a relationship between tactile sensitivity and 
variation in finger ridges, we have measured the tactile sensitivity of the tip of finger IV of the right hand by using sets of ridged surfaces with different densities of ridges. Several indices of tactile sensitivity performance have then been compared with certain dermatoglyphic characteristics on the tip of this finger.

The ring finger was selected for this test on the basis of results from a pilot study on 19 subjects in which tactile sensitivity performance was measured on fingers II (initially favoured) and IV of the right hand. Finger IV showed higher repeatability between tests and consistency within a test than finger II in tactile sensitivity threshold. We attribute this to the fact that the index finger is more exposed to damage, although mean performance did not appear to differ between these two fingers. We decided that the greater reliability of tactile sensitivity assessinent was more important in this study than the greater pattern variety found on the index finger.

\section{Methods and samples}

\section{Tactile sensitivity testing}

Tactile sensitivity has been tested using Tactile Evaluation Kit Surfaces, with varying densities of parallel ridges. The surfaces were designed by Professor I. DarianSmith (Department of Physiology, University of Melbourne, Melbourne, Australia). Ten sets of photo-etched plastic surfaces, each consisting of two separate units, have been used (Darian-Smith and Oke 1980). In each unit, there are two reference surfaces, each $34.5 \times 34.5 \mathrm{~mm}$, which have 46 parallel ridges, and one 'test' surface, which is different in that the ridges are fewer and further apart. In one unit of each set the test surface is situated between the two reference surfaces, in the other it is at the end. The difference in width of one complete ridge and groove $[(100 \times \mathrm{WR} / \mathrm{WT})-100]$ between test (WT) and reference (WR) surfaces gradually decreases from $20 \cdot 4 \%$ to $2 \cdot 7 \%$. The difference in this width (WT - WR in $\mu \mathrm{m}$ ) between test and reference surfaces is listed in table 1 . In all surfaces the width of a ridge was constant and it was the width of the groove which varied between test and reference surfaces.

Testing proceeded from the largest difference between reference and test surfaces to the smallest difference; the threshold of tactile sensitivity was taken as the smallest difference between reference and test surfaces (in $\mu \mathrm{m}$ ) at which the subject could reliably tell them apart.

Each set was presented so that one of the reference surfaces was always at the top and the subject had to choose whether the test surface was at the 'middle' or 'bottom'. The order in which the two units of each set were presented was decided from random

Table 1. Difference in width of one complete ridge and groove between test and reference surfaces (WT-WR).

\begin{tabular}{lcc}
\hline Set & Percentage difference & $\begin{array}{c}\text { Average difference between } \\
\text { ridge distances (in } \mu \mathrm{m})\end{array}$ \\
\hline$(1)$ & $20 \cdot 4$ & 140 \\
$(2)$ & $17 \cdot 9$ & 130 \\
$(3)$ & $15 \cdot 5$ & 110 \\
$(4)$ & $13 \cdot 1$ & 100 \\
$(5)$ & $12 \cdot 6$ & 90 \\
$(6)$ & $10 \cdot 9$ & 80 \\
$(7)$ & $8 \cdot 7$ & 60 \\
$(8)$ & $6 \cdot 1$ & 40 \\
$(9)$ & $3 \cdot 9$ & 30 \\
$(10)$ & $2 \cdot 7$ & 20 \\
\hline
\end{tabular}


number tables. The number of trials for each set was eight, but the subject was judged capable of discriminating at a given threshold even if he achieved only seven correct answers. The test for one set then, consisted of eight Bernoulli trials. The direction of finger movement was always from the top to the bottom, but the pressure exerted by the finger on surfaces could not be controlled; a subject was instructed to use the most efficient pressure, but there was considerable variability between subjects in this respect. Responses were timed and up to one minute was allowed for each reply. If a subject was unable to make a decision within this limit, he was instructed to give a 'best guess'. Each individual was tested twice in the same environment and the interval between the two tests was, on average, two days.

The test was performed on two male samples and one female sample of research workers aged 20-43 years. In order to reduce other influences on tactile sensitivity performance, care was taken not to include individuals with any sort of damage to the skin of the tested finger. Three groups of subjects were tested; 34 Polish males, 38 Polish females and 29 Australian males of European origin.

Before starting the first test, the subject was informed about its purpose and protocols and allowed to examine the surfaces. A curtain was placed between the subject and the surfaces so that he had no visual clues to discrimination. He was then presented with the first set, but the replies were not scored. If several replies in succession were correct and the subject seemed to have understood the instructions, the testing proper would begin. If replies were incorrect he was shown the actual surfaces that he failed to distinguish and was instructed with the same, or next set, until his appreciation of the task became satisfactory. The first testing always began with the easiest (1) set, were feedback was given, and then proceeded gradually until the number of correct answers was less than seven. After each set (except 1) was finished the subject was informed of the number of correct answers and sometimes reminded of the basic instructions or given additional advice.

The second testing session proceeded without repeating the instructions, but the subject was presented with a few surfaces to try before the test was started, with the same reinforcement as on the first occasion. If a subject performed very well during the first testing session, two or three easier sets of surfaces were often omitted on the second occasion. We made sure that during each test, the subject kept his fingers relatively dry and that distractions and interruptions were kept to a minimum. Although there were four left-handed individuals in our sample, the right finger was always tested.

\section{The variables}

Seven indices of tactile sensitivity were considered but only some of them were used in all statistical analyses:

(1) Threshold which is measured by the difference in the average inter-ridge distance (in $\mu \mathrm{m})$ between the reference and test surfaces (as tabled above) in the most difficult set correctly distinguished. Maximum threshold $\left(T_{\text {max. }}\right)$ refers to the threshold in the testing session in which performance was better, minimum threshold $\left(T_{\min }\right)$ to the threshold in the session (usually the first one), where performance was worse.

(2) Average time to response (AVT), in seconds, calculated from trials (within the $60 \mathrm{~s}$ time limit) in the session which produced the maximum threshold.

(3) Accuracy, represented by the total number of sets where all eight replies were correct, in the session which produced the maximum threshold result (N8) or in both sessions (T8). 
Table 2. Means, standard deviations and skewness $\left(g_{1}\right)$ of all variables included in this study in three samples: Australian males (MA), Polish males (MP) and Polish females $(\mathrm{F})$, and differences between samples in means and variances.

\begin{tabular}{|c|c|c|c|c|c|c|c|c|c|c|c|c|}
\hline \multirow[b]{2}{*}{ Variable } & \multicolumn{4}{|c|}{ Males (Australian) } & \multicolumn{4}{|c|}{ Males (Polish) } & \multicolumn{4}{|c|}{ Females } \\
\hline & $N$ & $\bar{x}$ & SD & $g_{1}$ & $N$ & $\bar{x}$ & SD & $g_{1}$ & $N$ & $\bar{x}$ & SD & $g_{1}$ \\
\hline Age & 29 & $28 \cdot 93$ & $5 \cdot 80$ & 0.99 & 34 & $31 \cdot 18^{*}$ & $5 \cdot 09$ & $0 \cdot 17$ & 38 & $33 \cdot 58^{* * *}$ & $4 \cdot 14$ & $0 \cdot 51$ \\
\hline$T_{\max }$ & 29 & $54 \cdot 48$ & $28 \cdot 73$ & $0 \cdot 79$ & 34 & $45 \cdot 29 * * *$ & $24 \cdot 15$ & $1 \cdot 03$ & 38 & $68 \cdot 16$ & $27 \cdot 89$ & 0.23 \\
\hline$T_{\min .}$ & 29 & $84 \cdot 52$ & $40 \cdot 98$ & $0 \cdot 07$ & 34 & $67 \cdot 94^{*}$ & $30 \cdot 92$ & $0 \cdot 32$ & 38 & $86 \cdot 32$ & $28 \cdot 04^{*}$ & -0.07 \\
\hline AVT & 29 & $24 \cdot 48^{* * *}$ & $9 \cdot 15$ & $0 \cdot 16$ & 34 & $16 \cdot 76$ & $7 \cdot 43$ & $1 \cdot 25$ & 38 & $19 \cdot 05^{* *}$ & $7 \cdot 09$ & $0 \cdot 40$ \\
\hline N8 & 29 & $4 \cdot 90$ & $2 \cdot 76$ & -0.43 & 34 & $5 \cdot 85^{* * *}$ & $2 \cdot 22$ & $-0 \cdot 71$ & 38 & $3 \cdot 50^{*}$ & $2 \cdot 02$ & 0.21 \\
\hline N78 & 29 & $6 \cdot 62^{*}$ & $2 \cdot 71^{*}$ & $-1 \cdot 28$ & 34 & $8 \cdot 03^{* * *}$ & $1 \cdot 78$ & $-1 \cdot 31$ & 38 & $6 \cdot 23$ & $1 \cdot 91^{*}$ & -0.57 \\
\hline T8 & 29 & $8 \cdot 14$ & $4 \cdot 94$ & $-0 \cdot 21$ & 34 & $9 \cdot 32^{* *}$ & $4 \cdot 13$ & -0.004 & 38 & $6 \cdot 24$ & $3 \cdot 84$ & $0 \cdot 28$ \\
\hline DT & 29 & $28 \cdot 62$ & $28 \cdot 50$ & $1 \cdot 23$ & 34 & $22 \cdot 64$ & $21 \cdot 92$ & 0.91 & 38 & $18 \cdot 16$ & $17 \cdot 68^{* *}$ & $1 \cdot 39$ \\
\hline$\overline{\mathrm{RB}}$ & 29 & $460 \cdot 10^{*}$ & $38 \cdot 22$ & $0 \cdot 15$ & 34 & $438 \cdot 71$ & $36 \cdot 81$ & $0 \cdot 24$ & 38 & $430 \cdot 32 * *$ & $37 \cdot 61$ & 0.41 \\
\hline RC & 29 & $15 \cdot 79$ & $8 \cdot 11^{*}$ & -0.93 & 34 & $17 \cdot 76$ & $5 \cdot 63$ & $-1 \cdot 02$ & 38 & $17 \cdot 86$ & $5 \cdot 89$ & -0.56 \\
\hline ARC & 29 & $23 \cdot 72$ & $15 \cdot 55$ & -0.11 & 34 & $25 \cdot 62$ & $13 \cdot 19$ & 0.24 & 38 & $24 \cdot 42$ & $12 \cdot 11$ & 0.30 \\
\hline PI & 29 & $1 \cdot 55$ & 0.51 & -0.87 & 34 & $1 \cdot 47$ & 0.61 & -0.42 & 38 & $1 \cdot 53$ & 0.51 & $-0 \cdot 10$ \\
\hline E & 29 & $7 \cdot 21^{*}$ & $3 \cdot 80$ & 0.61 & 33 & $9 \cdot 45$ & $3 \cdot 39$ & $1 \cdot 10$ & 35 & $8 \cdot 94$ & $3 \cdot 45$ & 0.34 \\
\hline J & 29 & $4 \cdot 38$ & $2 \cdot 48$ & 0.45 & 33 & $5 \cdot 36$ & $2 \cdot 36$ & $0 \cdot 10$ & 35 & $4 \cdot 97$ & $3 \cdot 20$ & $0 \cdot 46$ \\
\hline REJ & 29 & $2 \cdot 74$ & $2 \cdot 78^{* *}$ & $2 \cdot 58$ & 33 & $2 \cdot 28$ & $1 \cdot 53$ & $1 \cdot 19$ & 35 & $2 \cdot 31$ & $2 \cdot 10$ & $1 \cdot 83$ \\
\hline AP & 29 & $92 \cdot 59 * *$ & $15 \cdot 75$ & $0 \cdot 37$ & 34 & $81 \cdot 71$ & $12 \cdot 02$ & $0 \cdot 24$ & 37 & $76 \cdot 57^{* * *}$ & $12 \cdot 82$ & $1 \cdot 10$ \\
\hline RG & 29 & $2 \cdot 28$ & $0 \cdot 75$ & $-0 \cdot 51$ & 34 & $2 \cdot 06^{* *}$ & 0.69 & -0.08 & 38 & $2 \cdot 58$ & 0.60 & -1.06 \\
\hline
\end{tabular}

${ }^{*} 0.01<P<0.05,{ }^{* *} 0.001<P<0.01,{ }^{* * *} P<0.001$

Significant differences between MA and MP marked in MA columns.

Significant differences between MP and F marked in MP columns.

Significant differences between $\mathrm{MA}$ and $\mathrm{F}$ marked in $\mathrm{F}$ columns. 
(4) The sum of seven and eight correct answers from the testing session which resulted in the maximum threshold (N78); although this variable is almost the equivalent of $T_{\max }$, it was thought to give more accurate estimates in cases in which the evaluation of the threshold was equivocal.

(5) The difference between the maximum and minimum threshold (DT).

Finger prints were taken using black ink and shiny paper, which ensured reliable scoring of the minute properties of ridges. Pressure of the finger on the paper was slight and controlled by the investigator. Dermatoglyphic analysis was performed without knowledge of the results of tactile sensitivity performance in the individuals tested.

Nine finger-pattern characteristics have been included: ridge breadth or density (RB); ridge count (RC); absolute ridge count (ARC); pattern intensity (PI); number of ends (E) and junctions (J) within the limited area, and classified after Loesch (1973); ends to junctions ratio (REJ); the angle representing the convexity of a pattern (AP) and ridge-groove width ratio (RG). All these variables have been described in detail in another paper and associations between them have also been presented (Loesch and Martin 1984).

\section{Results}

Mean values, standard deviations and skewness of the distributions of all tactile sensitivity variables included here are given in table 2 . The distributions of most tactile sensitivity measures are skewed but only significantly so for N78 and DT in males. Transformation of these variables to remove skewness produced only trivial changes in values of the correlation coefficients.

Pairwise comparisons between all three samples indicate that females have lower tactile sensitivity than males in that their threshold is higher and their accuracy of discrimination between different surfaces is lower.

However, there is no indication of a sex difference in the average time of decisionmaking, which is longest in Australian males and shortest in Polish males. Observation

Table 3. Correlations between tactile sensitivity variables in female sample $(F)$, male samples combined (M) and all samples combined (A).

\begin{tabular}{|c|c|c|c|c|c|c|c|c|}
\hline & & $T_{\max }$ & $T_{\min }$ & N8 & N78 & AVT & DT & Age \\
\hline$T_{\max }$ & & $\begin{array}{l}\mathrm{M} \\
\mathrm{F}\end{array}$ & $\begin{array}{l}0 \cdot 68^{* * *} \\
0 \cdot 80^{* * *}\end{array}$ & $\begin{array}{l}-0 \cdot 84^{* * *} \\
-0.76^{* * *}\end{array}$ & $\begin{array}{l}-0 \cdot 80^{* * *} \\
-0.95^{* * *}\end{array}$ & $\begin{array}{l}0 \cdot 25 \\
0.23\end{array}$ & $\begin{array}{l}-0.05 \\
-0.31\end{array}$ & $\begin{array}{r}0.04 \\
-0.04\end{array}$ \\
\hline$T_{\min .}$ & A & $0 \cdot 71^{* * *}$ & $\begin{array}{c}\mathrm{M} \\
\mathrm{F}\end{array}$ & $\begin{array}{l}-0 \cdot 68^{* * *} \\
-0 \cdot 70^{* * *}\end{array}$ & $\begin{array}{l}-0 \cdot 52^{* * *} \\
-0 \cdot 81^{* * *}\end{array}$ & $\begin{array}{l}0.38^{* *} \\
0 \cdot 18\end{array}$ & $\begin{array}{l}0 \cdot 70^{* * *} \\
0 \cdot 32^{*}\end{array}$ & $\begin{array}{l}0.09 \\
0 \cdot 10\end{array}$ \\
\hline N8 & A & $-0 \cdot 83^{* * *}$ & $-0.69 * * *$ & $\begin{array}{l}\mathrm{M} \\
\mathrm{F}\end{array}$ & $\begin{array}{l}0 \cdot 68^{* * *} \\
0 \cdot 81^{* * *}\end{array}$ & $\begin{array}{l}-0 \cdot 33^{* *} \\
-0 \cdot 34^{*}\end{array}$ & $\begin{array}{r}-0.13 \\
0.09\end{array}$ & $\begin{array}{l}-0.12 \\
-0.12\end{array}$ \\
\hline N78 & A & $-0.85^{* * *}$ & $-0.61^{* * *}$ & $0 \cdot 74^{* * *}$ & $\begin{array}{c}\mathrm{M} \\
\mathrm{F}\end{array}$ & $\begin{array}{l}-0 \cdot 31^{*} \\
-0 \cdot 23\end{array}$ & $\begin{array}{l}0.07 \\
0.21\end{array}$ & $\begin{array}{l}0.06 \\
0.02\end{array}$ \\
\hline AVT & A & $0 \cdot 20^{*}$ & $0 \cdot 31^{* *}$ & $-0 \cdot 28^{* *}$ & $-0 \cdot 26^{* *}$ & $\begin{array}{c}\mathrm{M} \\
\mathrm{F}\end{array}$ & $\begin{array}{c}0.28^{*} \\
-0.07\end{array}$ & $\begin{array}{r}-0.18 \\
0.29\end{array}$ \\
\hline DT & A & -0.17 & $0 \cdot 57^{* * *}$ & -0.01 & $0 \cdot 14$ & $0 \cdot 20^{*}$ & $\begin{array}{c}M \\
F\end{array}$ & $\begin{array}{l}0.09 \\
0.20\end{array}$ \\
\hline Age & A & 0.12 & $0 \cdot 13$ & $-0 \cdot 22^{*}$ & -0.03 & -0.07 & 0.06 & \\
\hline
\end{tabular}

See table 2 for significance conventions. 
of behaviour patterns during the testing procedure suggests that this variable is considerably influenced by psychological factors, such as competitiveness or persistence, and this is supported by the association in males between average time (AVT) and learning (DT) (see table 3).

High correlations between the tactile sensitivity measures, $T_{\max }, T_{\min .}, \mathrm{N} 8$ and N78 demonstrate internal reliability of the results of testing. Low (but still significant) correlations between AVT and tactile sensitivity confirm that the time of decisionmaking is, to a large extent, an independent variable that is partly determined by influences irrelevant to skin perception.

Correlations with age are generally negligible except for the low but significant correlation, in all samples combined, between the accuracy of tactile sensitivity performance (N8) and the age of the subject. However, these low values may be partly accounted for by the intentionally limited age range of the sample.

\section{Dermatoglyphic variables}

Comparison of means between all three samples and variances of dermatoglyphic variables (table 2) shows much greater homogeneity. The breadth of ridges (RB) is greater in males, especially in the Australian sample, ridge-groove width ratio (RG) is greater in females, and males tend to have a more convex pattern shape (AP), especially the Australians.

Because properties of patterns and single ridges are not independent, we have estimated correlations between all variables and these are presented in another paper, together with the results of factor analysis (Loesch and Martin 1984). Some correlations, like those between pattern intensity and ridge count, pattern intensity and convexity of pattern, the negative correlation between ridge count and ridge breadth, or between the number of ends and junctions, are all predictable or have been reported before. Others, including the high negative correlation between ridge breadth and the intensity of minutiae, especially of ends, and the somewhat lower correlation between the number of junctions and the type of pattern are worthy of note. Generally, these intercorrelations, like those between the tactile sensitivity variables, confirm the internal consistency and reliability of the dermatoglyphic analysis applied here.

\section{Tactile sensitivity and dermatoglyphic variables}

Correlation coefficients (and their two-tailed significance) between tactile sensitivity performance and finger ridge patterns are presented in table 4 . Significant correlations occur between several tactile sensitivity measures and pattern intensity (PI) in both sexes, indicating that higher sensitivity is associated with lower pattern intensity. In males, higher sensitivity is related to a greater number of junctions (J, REJ) but this is not evident in females. On the other hand, there is a negative correlation (greater in females than males) between accuracy of tactile perfornance (N8 and T8) and the ridge-groove width ratio $(R G)$ which suggests that having narrower ridges than grooves confers higher sensitivity. Correlations between the time of decision making (AVT) and dermatoglyphic variables are less pronounced except for its association with lower convexity (AP) of pattern, in males only. Using non-parametric tests (Kendall's $\tau$ and Spearman's $r_{s}$ ) with the discrete variables PI and RG, generally decreases coefficients slightly but does not change their significance levels, except in the cases of PI with $T_{\min }$. (for all samples combined) and RG with N8 (in males) which become significant.

We have observed that junctions and convexity of patterns in males, ridge-groove width ratio predominantly in females and pattern intensity in both sexes are related to 
Table 4. Correlation coefficients between tactile sensitivity variables and dermatoglyphic traits in the female sample (F), male samples combined $(N)$ and all samples combined (A).

\begin{tabular}{|c|c|c|c|c|c|c|c|}
\hline & & $T_{\max }$ & $T_{\min }$ & AVT & N8 & T8 & DT \\
\hline RB & $\begin{array}{l}\mathrm{F} \\
\mathrm{M} \\
\mathrm{A}\end{array}$ & $\begin{array}{r}0.17 \\
-0.09 \\
-0.07\end{array}$ & $\begin{array}{r}0.18 \\
-0.04 \\
-0.01\end{array}$ & $\begin{array}{l}0.04 \\
0 \cdot 12 \\
0 \cdot 11\end{array}$ & $\begin{array}{r}-0.28 \\
0.03 \\
0.02\end{array}$ & $\begin{array}{r}-0.20 \\
0.06 \\
0.04\end{array}$ & $\begin{array}{l}0.03 \\
0.02 \\
0.06\end{array}$ \\
\hline$\overline{R C}$ & $\begin{array}{l}\mathrm{F} \\
\mathrm{M} \\
\mathrm{A}\end{array}$ & $\begin{array}{l}0 \cdot 18 \\
0 \cdot 14 \\
0 \cdot 17\end{array}$ & $\begin{array}{l}0.04 \\
0.08 \\
0.08\end{array}$ & $\begin{array}{l}0 \cdot 16 \\
0 \cdot 08 \\
0 \cdot 10\end{array}$ & $\begin{array}{r}0.04 \\
-0.20 \\
-0.15\end{array}$ & $\begin{array}{l}-0.06 \\
-0.12 \\
-0.12\end{array}$ & $\begin{array}{l}-0.22 \\
-0.01 \\
-0.07\end{array}$ \\
\hline$\overline{\text { ARC }}$ & $\begin{array}{l}\mathrm{F} \\
\mathrm{M} \\
\mathrm{A}\end{array}$ & $\begin{array}{l}0.22 \\
0 \cdot 15 \\
0 \cdot 16\end{array}$ & $\begin{array}{l}0 \cdot 11 \\
0 \cdot 15 \\
0 \cdot 13\end{array}$ & $\begin{array}{l}0 \cdot 17 \\
0 \cdot 09 \\
0 \cdot 11\end{array}$ & $\begin{array}{l}-0.09 \\
-0.22 \\
-0.16\end{array}$ & $\begin{array}{l}-0.18 \\
-0.16 \\
-0.16\end{array}$ & $\begin{array}{r}-0.16 \\
0.06 \\
0.00\end{array}$ \\
\hline PI & $\begin{array}{l}\mathrm{F} \\
\mathrm{M} \\
\mathrm{A}\end{array}$ & $\begin{array}{l}0 \cdot 30 \\
0 \cdot 14 \\
0 \cdot 20^{*}\end{array}$ & $\begin{array}{l}0 \cdot 33^{*} \\
0 \cdot 11 \\
0 \cdot 18\end{array}$ & $\begin{array}{l}0 \cdot 30 \\
0.08 \\
0 \cdot 13\end{array}$ & $\begin{array}{l}-0 \cdot 32 \\
-0 \cdot 25^{*} \\
-0 \cdot 27^{* *}\end{array}$ & $\begin{array}{l}-0 \cdot 34^{*} \\
-0 \cdot 20 \\
-0.25^{*}\end{array}$ & $\begin{array}{l}0.05 \\
0.03 \\
0.03\end{array}$ \\
\hline $\bar{E}$ & $\begin{array}{l}\mathrm{F} \\
\mathrm{M} \\
\mathrm{A}\end{array}$ & $\begin{array}{l}0 \cdot 16 \\
0.08 \\
0 \cdot 12\end{array}$ & $\begin{array}{l}0.11 \\
0.00 \\
0.04\end{array}$ & $\begin{array}{r}0.03 \\
-0.06 \\
-0.04\end{array}$ & $\begin{array}{r}0.04 \\
-0.12 \\
-0.09\end{array}$ & $\begin{array}{l}-0.02 \\
-0 \cdot 13 \\
-0 \cdot 10\end{array}$ & $\begin{array}{r}0.09 \\
-0.06 \\
-0.08\end{array}$ \\
\hline $\mathrm{J}$ & $\begin{array}{l}\mathrm{F} \\
\mathrm{M} \\
\mathrm{A}\end{array}$ & $\begin{array}{r}0.01 \\
-0.24 \\
-0.12\end{array}$ & $\begin{array}{l}-0 \cdot 02 \\
-0 \cdot 21 \\
-0 \cdot 14\end{array}$ & $\begin{array}{l}-0 \cdot 10 \\
-0 \cdot 15 \\
-0 \cdot 13\end{array}$ & $\begin{array}{l}0 \cdot 03 \\
0 \cdot 28^{*} \\
0 \cdot 17\end{array}$ & $\begin{array}{c}-0.03 \\
0.27^{*} \\
0.14\end{array}$ & $\begin{array}{l}-0.05 \\
-0.06 \\
-0.05\end{array}$ \\
\hline REJ & $\begin{array}{l}\mathrm{F} \\
\mathrm{M} \\
\mathrm{A}\end{array}$ & $\begin{array}{l}0 \cdot 26 \\
0.28^{*} \\
0.24^{*}\end{array}$ & $\begin{array}{l}0 \cdot 32 \\
0 \cdot 17 \\
0 \cdot 20\end{array}$ & $\begin{array}{l}0 \cdot 16 \\
0 \cdot 13 \\
0 \cdot 14\end{array}$ & $\begin{array}{l}-0 \cdot 19 \\
-0 \cdot 30^{*} \\
-0.24^{*}\end{array}$ & $\begin{array}{l}-0.16 \\
-0.25 \\
-0.20\end{array}$ & $\begin{array}{r}0.08 \\
-0.03 \\
0.01\end{array}$ \\
\hline$\overline{\mathrm{AP}}$ & $\begin{array}{l}\mathrm{F} \\
\mathrm{M} \\
\mathrm{A}\end{array}$ & $\begin{array}{r}0.06 \\
0.15 \\
-0.01\end{array}$ & $\begin{array}{l}0.09 \\
0.16 \\
0.07\end{array}$ & $\begin{array}{r}-0.06 \\
0.31^{*} \\
0.23^{*}\end{array}$ & $\begin{array}{l}-0.18 \\
-0.15 \\
-0.02\end{array}$ & $\begin{array}{l}-0.17 \\
-0.11 \\
-0.03\end{array}$ & $\begin{array}{l}0.04 \\
0.06 \\
0.10\end{array}$ \\
\hline $\mathrm{RG}$ & $\begin{array}{l}\mathrm{F} \\
\mathrm{M} \\
\mathrm{A}\end{array}$ & $\begin{array}{l}0.13 \\
0.06 \\
0.17\end{array}$ & $\begin{array}{l}0.18 \\
0.11 \\
0.16\end{array}$ & $\begin{array}{l}0 \cdot 18 \\
0.07 \\
0.07\end{array}$ & $\begin{array}{l}-0 \cdot 38^{*} \\
-0.20 \\
-0 \cdot 33^{* *}\end{array}$ & $\begin{array}{l}-0.34^{*} \\
-0.12 \\
-0.25^{*}\end{array}$ & $\begin{array}{l}0.08 \\
0.08 \\
0.03\end{array}$ \\
\hline
\end{tabular}

See table 2 for significance conventions.

tactile sensitivity performance. However, the fact that many dermatoglyphic variables are themselves intercorrelated, may obscure the interpretation of the correlations found with tactile sensitivity measures. In order to control for these complex relationships, each tactile sensitivity character has been regressed on all dermatoglyphic variables in stepwise multiple linear regression. The results of this analysis show that junctions in males and pattern intensity in females account for most variance in sensitivity variables, even when other correlated variables are entered into the regression equation. Two exceptions are the average time of decision making (AVT) in males, which is predominantly related to pattern convexity (AP), and accuracy (N8) in females where RG accounts for more variance than PI although both predictors are significant. The proportions of variance in tactile sensitivity variables accounted for $\left(\Delta r^{2}\right)$ by stepwise entry of dermatoglyphic predictor variables into the regression equations are shown in table 5 .

Because pattern intensity is a meristic character, a comparison by $t$-test between groups separated according to discrete values has also been performed. Tactile sensitivity variables have been compared between two pattern intensity groups; because only four subjects had arches on finger IV these have been pooled with loops and this group has been compared with those subjects possessing whorls. The means of 
Table 5. Proportions of variance in tactile sensitivity measures accounted for $\left(\Delta r^{2}\right)$ by stepwise entry of dermatoglyphic predictor variables into multiple regression equations.

\begin{tabular}{|c|c|c|c|c|c|}
\hline \multirow[b]{3}{*}{$\begin{array}{l}\text { Dependent } \\
\text { variable }\end{array}$} & \multicolumn{5}{|c|}{ Sequence of independent variables } \\
\hline & \multicolumn{3}{|c|}{ Males } & \multicolumn{2}{|c|}{ Females } \\
\hline & Step & Predictor & $\left(\Delta r^{2}\right)$ & Predictor & $\left(\Delta r^{2}\right)$ \\
\hline$T_{\max }$ & $\begin{array}{l}1 \\
2 \\
3 \\
4 \\
5 \\
6\end{array}$ & $\begin{array}{l}\mathrm{J} \\
\text { AP } \\
\mathrm{RB} \\
\mathrm{RG} \\
\mathrm{E}\end{array}$ & $\begin{array}{l}0.057 \\
0.013 \\
0.011 \\
0.008 \\
0.001\end{array}$ & $\begin{array}{l}\text { PI } \\
\text { RG } \\
\text { RC } \\
\text { E } \\
\text { RB } \\
\text { RC }\end{array}$ & $\begin{array}{l}0.128 \\
0.019 \\
0.019 \\
0.011 \\
0.012 \\
0.004\end{array}$ \\
\hline$T_{\min }$ & $\begin{array}{l}1 \\
2 \\
3 \\
4 \\
5 \\
6 \\
7 \\
8\end{array}$ & $\begin{array}{l}\text { J } \\
\text { AP } \\
\text { RG } \\
\text { RB } \\
\text { RC } \\
\text { ARC } \\
\text { PI }\end{array}$ & $\begin{array}{l}0 \cdot 045 \\
0 \cdot 018 \\
0.018 \\
0.002 \\
0 \cdot 002 \\
0.017 \\
0.000\end{array}$ & $\begin{array}{l}\text { PI } \\
\text { ARC } \\
\text { RG } \\
\text { J } \\
\text { RC } \\
\text { E } \\
\text { AP } \\
\text { RB }\end{array}$ & $\begin{array}{l}0.256 \\
0.074 \\
0.035 \\
0.034 \\
0.021 \\
0.007 \\
0.008 \\
0.000\end{array}$ \\
\hline AVT & $\begin{array}{l}1 \\
2 \\
3 \\
4 \\
5 \\
6\end{array}$ & $\begin{array}{l}\text { AP } \\
\text { RB } \\
\text { RG } \\
\text { J } \\
\text { E } \\
\text { RC }\end{array}$ & $\begin{array}{l}0.102 \\
0.013 \\
0.009 \\
0.010 \\
0.005 \\
0.000\end{array}$ & $\begin{array}{l}\text { PI } \\
\text { ARC } \\
\text { RC } \\
\text { RB } \\
\text { E } \\
\text { J }\end{array}$ & $\begin{array}{l}0.069 \\
0.032 \\
0.050 \\
0.011 \\
0.008 \\
0.003\end{array}$ \\
\hline N8 & $\begin{array}{l}1 \\
2 \\
3 \\
4 \\
5 \\
6\end{array}$ & $\begin{array}{l}\text { J } \\
\text { RG } \\
\text { PI } \\
\text { AP } \\
\text { E } \\
\text { RB }\end{array}$ & $\begin{array}{l}0.080 \\
0.051 \\
0.015 \\
0.010 \\
0.012 \\
0.002\end{array}$ & $\begin{array}{l}\text { RG } \\
\text { PI } \\
\text { ARC } \\
\text { RC } \\
\text { J } \\
\text { E }\end{array}$ & $\begin{array}{l}0.127 \\
0.061 \\
0.035 \\
0.042 \\
0.013 \\
0.006\end{array}$ \\
\hline $\mathrm{N} 7,8$ & $\begin{array}{l}-1 \\
2 \\
3 \\
4 \\
5 \\
6 \\
7 \\
8\end{array}$ & $\begin{array}{l}\text { J } \\
\text { AP } \\
\text { ARC } \\
\text { RC } \\
\text { RB } \\
\text { E } \\
\text { RG } \\
\text { PI }\end{array}$ & $\begin{array}{l}0.053 \\
0.036 \\
0.010 \\
0.007 \\
0.012 \\
0.011 \\
0.008 \\
0.002\end{array}$ & $\begin{array}{l}\text { PI } \\
\text { RG } \\
\text { E } \\
\text { RB } \\
\text { AP } \\
\text { RC }\end{array}$ & $\begin{array}{l}0.152 \\
0.028 \\
0.015 \\
0.017 \\
0.007 \\
0.003\end{array}$ \\
\hline
\end{tabular}

sensitivity characters for both pattern intensity categories are shown in table 6 , for males, females and all samples combined. In each sex, particularly females, individuals with whorls are less sensitive in that they have a higher threshold ( $T_{\max }$ and $\left.T_{\min .}\right)$, give less accurate answers (N78, N8 and T8) and take longer to respond than those with lower pattern intensities. If the number of cases is increased by combining all samples, the difference becomes significant for all tactile sensitivity measurements except $T_{\max }$.

The same argument applies to the ridge-groove width ratio which takes three discrete values, and the difference in accuracy of tactile discrimination (N8) between these categories is shown in table 7. The results indicate that in subjects with wider grooves than ridges $(\mathrm{RG}=1)$ the number of all correct answers is greater than in subjects with wider ridges than grooves $(R G=3)$. The difference is significant in all 
Table 6. Comparison of means and variances for tactile sensitivity measures between subsamples with PI $\leqslant 1$ (loops and arches), and PI = 2 (whorls) for males, females and for sexes combined. Significance of difference between means is indicated.

\begin{tabular}{|c|c|c|c|c|c|c|c|c|c|c|c|c|}
\hline \multirow[b]{3}{*}{ Character } & \multicolumn{4}{|c|}{ Females $(N=38)$} & \multicolumn{4}{|c|}{ Males combined $(N=63)$} & \multicolumn{4}{|c|}{ All combined $(N=101)$} \\
\hline & \multicolumn{2}{|c|}{$\mathrm{PI} \leqslant 1$} & \multicolumn{2}{|c|}{$P I=2$} & \multicolumn{2}{|c|}{$P I \leqslant 1$} & \multicolumn{2}{|c|}{$\mathrm{PI}=2$} & \multicolumn{2}{|c|}{$P I \leqslant 1$} & \multicolumn{2}{|c|}{$P I=2$} \\
\hline & $\bar{x}$ & SD & $\bar{x}$ & SD & $\bar{x}$ & SD & $\bar{x}$ & SD & $\bar{x}$ & SD & $\bar{x}$ & SD \\
\hline $\begin{array}{l}T_{\max } \\
T_{\min .}\end{array}$ & $\begin{array}{l}59 \cdot 44 \\
76 \cdot 67^{*}\end{array}$ & $\begin{array}{l}28 \cdot 79 \\
25 \cdot 67\end{array}$ & $\begin{array}{l}76 \cdot 00 \\
95 \cdot 00^{*}\end{array}$ & $\begin{array}{l}25 \cdot 22 \\
27 \cdot 82\end{array}$ & $\begin{array}{l}46 \cdot 66 \\
69 \cdot 00\end{array}$ & $\begin{array}{l}23 \cdot 39 \\
33 \cdot 87\end{array}$ & $\begin{array}{l}52 \cdot 12 \\
81 \cdot 54\end{array}$ & $\begin{array}{l}29 \cdot 36 \\
38 \cdot 38\end{array}$ & $\begin{array}{l}51 \cdot 46 \\
71 \cdot 88^{*}\end{array}$ & $\begin{array}{l}26 \cdot 01 \\
30 \cdot 99\end{array}$ & $\begin{array}{l}61 \cdot 13 \\
86 \cdot 62^{*}\end{array}$ & $\begin{array}{l}29 \cdot 91 \\
35 \cdot 11\end{array}$ \\
\hline N8 & $4 \cdot 17$ & $2 \cdot 33$ & $2 \cdot 90$ & $1 \cdot 52$ & $5 \cdot 90$ & $2 \cdot 23$ & $4 \cdot 96$ & $2 \cdot 69$ & $5 \cdot 25^{*}$ & $2 \cdot 40$ & $4 \cdot 19^{*}$ & $2 \cdot 51$ \\
\hline T8 & $7 \cdot 61^{*}$ & $4 \cdot 31$ & $5 \cdot 00^{*}$ & $2 \cdot 94$ & $9 \cdot 60$ & $4 \cdot 04$ & 8.03 & $4 \cdot 86$ & $8.95^{*}$ & $4 \cdot 21$ & $6 \cdot 88^{*}$ & $4 \cdot 46$ \\
\hline N78 & $6 \cdot 94^{*}$ & $1 \cdot 89$ & $5 \cdot 60^{*}$ & $1 \cdot 73$ & $7 \cdot 77$ & $2 \cdot 18$ & $7 \cdot 03$ & $2 \cdot 47$ & $7 \cdot 45^{*}$ & $2 \cdot 09$ & $6 \cdot 49^{*}$ & $2 \cdot 31$ \\
\hline$N$ & 18 & & 20 & & 30 & & 33 & & 48 & & 53 & \\
\hline
\end{tabular}

$*_{0}^{*} 01<P<0.05$ 
Table 7. Comparison of tactile sensitivity performance (N8) between subsamples with ridge/groove ratings 1,2 and 3 , respectively, in all samples combined.

\begin{tabular}{llcc}
\hline RG & $N$ & $\bar{x}$ & SD \\
\hline 1 & 14 & $5 \cdot 86$ & $2 \cdot 77$ \\
2 & 41 & $5 \cdot 32$ & $2 \cdot 26$ \\
3 & 46 & $3 \cdot 78$ & $2 \cdot 36$ \\
\hline
\end{tabular}

$F($ d.f., 2,98$)=6 \cdot 46, P=0 \cdot 002$.

samples combined, but it is more pronounced in females than in males. These results are thus consistent with those obtained in the correlation and regression analysis.

\section{Discussion}

The results of this study provide evidence for a relationship between tactile sensitivity and ridge patterns on finger IV of the right hand. It is not unexpected that the correlations are generally low, as there must be many factors which influence such an important function as skin tactile perception. Although the complexity of intercorrelated dermatoglyphic variables on the tip of the finger makes it difficult to ascertain which of these are most directly involved in peripheral mechanisms of skin sensation, our results give some indication as to the direction in which further investigations should proceed.

In males, sensitivity of touch when the finger is moved over a surface is facilitated by a greater number of junctions and also by lower pattern intensity (i.e. more loops), which is correlated with the former. In females, greater tactile sensitivity performance is consistently associated with lower values of finger pattern intensity and with lower ridge-groove width ratio. Wider spaces between the ridges thus appear to be more advantageous for tactile perception. The stronger relationship in females may be accounted for by the fact that their ridges are less prominent than those of males. These apparent sex differences in the mechanism of skin perception require studies of the relationship between tactile sensitivity and measurements of the width of grooves and the width as well as height of ridges.

From these results we can predict the optimum combination of dermatoglyphic features on the fingertip for greatest tactile sensitivity. This would be a loop with relatively low ridge count, many junctions and narrower ridges than grooves.

The contribution of junctions to tactile sensitivity performance, especially conspicuous in males, may support the view of Quilliam (1978), that the stiffness of the external papillary ridges creates vibratory effects which are propagated through the inner layers of skin where they are detected primarily by deeply placed receptors (Pacinian corpuscles) and also by more superficial ones such as Meissner bodies, Merkel's discs or papillary nerve endings. It is possible that ends, which are interruptions in the stream of parallel ridges, may interfere with this vibratory effect, while junctions may enhance it. It should be noted that our subjects could achieve no discrimination between surfaces without movement of the finger. Since Pacinian corpuscles respond specifically to vibratory stimuli, their role in tactile sensitivity performance might be better understood if the results of the test applied here were compared in one and the same individual with vibratory perception.

An alternative explanation may be that there are simply more Meissner bodies at the site of junctions, which play the main role in this type of tactile perception. It has been shown that Meissner corpuscles occupy the largest dermal papillae. Okajima (1979) 
observed that these are scattered among average-size papillae, but he did not examine specifically their relationship with junctions or any other types of minutiae and his observations mainly concerned palmar and sole areas. Apart from microscopic evidence, a comparison of tactile sensitivity in different age groups may give an answer to this problem, as the number of Meissner's bodies is known to decline rapidly with age. Relationships between the distribution of other skin receptors such as free intraepidermal nerve endings or papillary nerve endings, and minutiae types, have also not yet been established.

It is worth noting here that in another study (Loesch, Eaves and Heath, in preparation) where we found evidence for genetical epistasis in variation for pattern finger intenstiy, it was inferred that genetic non-additivity, in the form of epistatic interaction, acts from both extremes towards the mean. According to Mather (1973), this would suggest a history of stabilizing selection with the highest and lowest pattern intensities being selected against in favour of intermediate values, close to current population means. In this study we have found intermediate values of pattern intensity to be advantageous in tactile sensitivity performance. However, there may be other selective mechanisms responsible for the observed genetical non-additivity. This argument may not apply in the case of intensity of junctions since the heritability of this variable appears to be low (reviewed in Loesch 1983).

It may be of interest to mention the observations of Féré (1895) referred to earlier in this paper, that two-point discrimination is better if the points are placed transversally to the direction of ridges rather than parallel to them. He also found better two-point discrimination on the radial side of all fingertips except the thumb (which is in opposition) and postulated that the predominant presence of ulnar loops on human fingers may enhance touch perception.

Despite certain inconsistencies, the results of our experiment contradict the common belief that dermatoglyphic characters are functionally 'neutral' and they suggest a certain combination of fingertip characteristics which may be selectively advantageous. This experiment needs to be repeated on more than one finger but our protocol took about two hours per subject and boredom and fatigue are important factors in any sensory test. A quick and accurate test of tactile sensitivity is greatly needed. More critical results might be obtained by pre-selecting subjects with extreme values of dermatoglyphic features shown here to be related to tactile sensitivity performance.

\section{Acknowledgements}

We should like to thank Professor Ian Darian-Smith and Mrs Lin Oke of the Department of Physiology, University of Melbourne, for the loan of the Tactile Sensitivity Evaluation Kit and for advice in the design of this experiment. We particularly appreciate the patience and cooperation of our subjects. D. L. is grateful to the Australian Department of Education for an Australian-European Award which enabled this work to be initiated while visiting The Australian National University; a major part of this study was supported by the Polish Academy of Sciences within project no. 09.7. D.L.'s permanent address is Department of Genetics, Psychoneurological Institute, Warsaw. 


\section{References}

Babler, W.J., 1978, Prenatal selection and dermatoglyphic patterns. American Journal of Physical Anthropology, 48, 21-28.

Cauna, N., and Ross, L. L., 1960, The fine structure of Meissner's touch corpuscles of human fingers. Journal of Biophysical and Biochemical Cytology, 8, 467-482.

Cummins, H., and Midlo, C., 1943, Finger Prints, Palms and Soles. (Philadelphia: Blakison).

DARIAN-SMITH, I., and OKE, L.E., 1980, Peripheral neural representation of the spatial frequency of a grating moving across the monkey's finger pad. Journal of Physiology, 309, 117-133.

Féré, CH., 1895, Note sur la sensibilité de la pulpe des doigts. Société de biologie (Paris), 47, 657-660.

FÉrÉ CH., 1896, Des empreintes digitales dans l'étude des fonctions de la main. Société de biologie (Paris), 48, 1114-1117.

LOESCH, D., 1973, Minutiae and clinical genetics. Journal of Mental Deficiency Research, 17, 97-105.

LOESCH, D., and MARTIN, N. G., 1984, Relationships between minute characteristics of finger ridges and pattern size and shape. Annals of Human Biology, 11, 125-132.

Loesch, D., and Martin, N. G., 1983, Relationships between minute characteristics of finger ridges and pattern size and shape. Annals of Human Biology (Submitted).

Martin, N.G., Loesch, D.Z., and JARDine, R., 1982, Evidence for directional non-additivity in the genetics of finger ridge counts. Annals of Human Biology, 9, 253-263.

MATHER, K., 1973, Genetical Structure of Populations. (London: Chapman and Hall).

OKajima, M., 1979, Dermal and epidermal structures of the volar skin. In Dermatoglyphics - Fifty Years Later, edited by W. Wertelecki and Ch. Plato. The National Foundation - March of Dimes. (New York: Alan R. Liss), pp. 179-198.

Quilliam, T. A., 1978, The structure of finger print skin. In Active Touch: The Mechanism of Recognition of Objects by Manipulation, edited by G. Gordon (Oxford: Pergamon Press), pp. 1-18.

RONGE, H., 1943, Altersveränderungen der Meissnerschlen Körperchen in der Fingerhaut. Zeitschrift für mikroskopisch-anatomische Forschung, 54, 167-177.

Schlaginhaufen, O., 1905, Das Hautleistensystem der Primatenplanta unter Mitberücksichtigung der Palma. Morphologisches Jahrbuch, 33, 577-671.

Address correspondence to Dr D. Z. Loesch, Department of Population Biology, Research School of Biological Sciences, Australian National University, P.O. Box 475, Canberra City, ACT 2601, Australia.

Zusammenfassung. Taktile Sensitivität wurde bei 101 normalen Individuen (38 Frauen und 63 Männern) von europäischem Ursprung gemessen, außerdem verglichen mit Merkmalen des Hautleistenmusters des IV. Fingers der rechten Hand. Es gibt eine Verknüpfung der taktilen Sensibilitätsleistung mit dem Mustertyp, besonders bei Frauen, ebenso mit der Zahl der Verzweigungen innerhalb des Musters, besonders bei Männern. Der mögliche Ursprung der Geschlechtsunterschiede der taktilen Sensibilität und ihre Verknüpfung mit dermatoglyphischen Variablen wird diskutiert. Ohne Berücksichtigung der Geschlechtsunterschiede scheint die optimale taktile Sensibilitätsleistung mit Schleifenmustern mittlerer Größe verknüpft zu sein, die eine größere Zahl von verzweigungen als Enden haben und deren Hautrillen breiter sind als die Hautleisten. Die mögliche evolutionäre Bedeutung dieser Verknüpfungen wird im Zusammenhang mit Hinweisen auf epistatische genetische Variation für Musterintensität diskutiert.

Résumé. La sensibilité tactile a été mesurée chez 101 individus normaux ( 38 femmes et 63 hommes) d'origine européenne, et comparée aux caractéristiques du dessin des crêtes du bout du IVé doigt de la main droite. Il y a une relation de la sensibilité tactile avec le type de dessin, particulièrement chez la femme, et aussi avec le nombre de jonctions dans le dessin, particulièrement chez l'homme. L'origine possible des différences sexuelles de sensibilité tactile et de ses relations avec les variables dermatoglyphiques est discutée. En dépit de différences sexuelles, la sensibilité tactile optimale semble associée aux dessins de boucle de grandeur moyenne qui ont un plus grand nombre de jonctions que de terminaisons et aussi ont des creux plus larges que les crêtes. La signification évolutive possible de ces assocations est discutée en relation avec les signes de variation génétique épistatique pour l'intensité des dessins. 